\title{
The semiotic life cycle and The Symbolic Species
}

\author{
Tyler James Bennett \\ Department of Semiotics, University of Tartu \\ Jakobi St. 2, 51014 Tartu, Estonia \\ e-mail: bennett@ut.ee
}

\begin{abstract}
In The Symbolic Species (1997) Terrence Deacon identifies human verbal language acquisition as the first and foremost evolutionary threshold where symbol use happens, with all the concomitant adaptive advantages it affords, but along with these advantages in this book and elsewhere he alludes to certain disadvantages that result from symbols. To describe these disadvantages he uses words like maladaptation, parasitism, cognitive penumbra, and other hyperbolic terms. He does so offhandedly, either in connection with the results of some laboratory experiments, or simply in disconnected ominous generalizations, but never justifies these sign effects within the dominantly Peircean model of language acquisition that gives the book its title. In later works Deacon attempts to contextualize these generalizations within Richard Dawkins' theory of the meme. Deacon is sometimes disparaged for his supposedly imprecise or incorrect use of the sign theory of Charles Peirce to defend his claims about memes and symbols. The problem is not that Peirce should not be used in this way. In fact Deacon's book is a singular achievement in the application of Peirce. The problem is that Deacon's Peircean model is too simple. In fact Deacon's claim about the possible disadvantages of symbol use can be reinforced with a closer look at the mature, turn-of-the-century Peircean sign model. This preserves the theoretical integrity of The Symbolic Species and clarifies the relation between memes and signs.
\end{abstract}

Keywords: Charles Peirce, Terrence Deacon, symbol, sign degeneration, decontextualization

\section{Introduction}

The idea that verbal language ability affords some kind of disadvantage is by no means a novel suggestion. Such ideas do however feel out of place in Deacon's book, a work which with little exception relies only on verifiable hard science and research. In fact this aspect of the book is nowhere discussed in secondary literature, whether as a problem or even just a curiosity, unlike the issue of his use of the sign theory of Charles Peirce. When The Symbolic Species was first published in 1997 Peirce scholarship had 
not quite reached the pitch of popularity it has now, but since that time Deacon's book has received a considerable amount of criticism from Peirce scholars. The most common criticism has to do with Deacon's application of the icon-index-symbol trichotomy to broad evolutionary phases, culminating in his thesis that the symbolic threshold was crossed first by humans and is for the most part a strictly human affair exemplified by verbal language (Stjernfelt 2012). The other criticism he receives is that he uses a too simple model of Peircean semiosis. While the first criticism would be valid were Deacon's intent to employ a strictly Peircean basis for his model of verbal language acquisition, it is clear that this was not the case, and Deacon remains unapologetic for this (Deacon 2012a). Whether or not it is appropriate to attribute sign types to these broad evolutionary phases is related to the question of whether subsymbolic signs are really signs at all, a divisive issue for contemporary semiotics. We are forced to leave this debate in abeyance in order to address the far narrower, seldom discussed question of whether and how Deacon's attribution of disadvantages to symbol use can be justified within a Peircean framework.

\section{Peirce's symbols in The Symbolic Species}

As we see it, the strong claim in The Symbolic Species is Deacon's attack on the eliminative computationalist model of mind. This is the idea that the brain is comparable to a computer in the sense that, once a high enough computing power is achieved in computers, they will exhibit all the features we find in human minds capable of manipulating symbols in the way we do. By this argument mind as we know it is an epiphenomenon of chemical interactions in the brain, and concepts like purpose and intention are merely stand-ins for the more specific electrical and other physical properties that are their cause, and should be eliminated from any theory purporting to explain mind. Another implication is that, since the human mind experience is a product of a certain level of complexity in brain functions, within the brain there must be an area to which we can specifically point and say that this is unique to human brains, this is what makes verbal language possible. The vast middle section of The Symbolic Species, "Part II: Brain" is an extensive refutation of this claim.

According to Deacon's findings there is no specific area of the brain to which language can be attributed. The enlarged front-heavy neocortical area in humans does not explain verbal language use. Verbal language is the result of a global distributed function that somehow reorganizes pre-existing brain processes. In the vocabulary of Deacon's later book Incomplete Nature (2012), multiple contragrade processes conflict, producing new levels of orthograde organizational wholes which cannot be inferred from their constituent parts, and whose emergence is unpredictable. Needless to say, this new threshold of organizational and processing power that makes verbal language 
possible is what is called the symbolic threshold, and for Deacon it is the passing of this threshold which is unique to the human species. Whether or not Deacon is correct about this (about computationalist theories of mind, about the absence of the language organ, the emergent character of verbal language, or especially about the symbolic threshold being unique to humans), we leave it aside for now. What is important for this article is a characteristic that Deacon imputes to symbol use, one which he says is both the source of the evolutionary advantage that verbal language provides, while at the same time presenting a serious danger or disadvantage, a sort of double-edged sword that can even be portrayed as a maladaptation. The simplest example of the possible disadvantage that happens when signs become detached from the sub-symbolic comes from chimpanzee language acquisition experiments.

Two chimps are presented with two differently sized piles of candy and are asked to choose which one they want. Consistently they choose the larger pile. A complication is introduced such that the pile they choose is now given to the other chimp. After repeated trials the chimps display difficulty in being able to choose the smaller pile in order to receive the larger one, whereas when human children are subjected to the same experiment they have little to no difficulty in overcoming the complication and receiving the larger pile. The human children have a far easier time realizing that pointing to the larger pile of candy itself is at a remove from the occasion of receiving that pile.

The task poses a difficulty, not because the chimps are ambivalent about sharing or cannot assess what they want... but because the presence of such a salient reward undermines their ability to use the stimulus information against itself. (Deacon 1997: 414)

The conclusion of the researcher in this experiment is that the capability for symbol use that characterizes verbal language gives the human children an advantage. They realize after a few tries that the act of pointing to the larger pile indicates something other than receiving that pile. Later in the experiment the chimps are presented not with the actual piles of candy, but with numerals representing them, where the larger numeral is associated with the smaller pile and vice versa. They are then asked to gesture toward the numeral corresponding to the pile of candy they wish to receive. After several trials the chimps perform far better than they performed when presented with the actual piles in front of them. The actual presence of the piles of candy seems to interfere with the ability of the chimps to take a step back, so to speak, and perceive the remove of the larger pile itself from the occasion of receiving it. The piles themselves exert a too strong impression, whereas the symbols representing them provide a sensory distance that is easier to negotiate. When the pile itself is replaced with a symbol of that pile, this rudimentary use of a different kind of representation changes the chimps' perceptive inclinations. 
Ascending the representational hierarchy progressively frees responses from stimulus-driven immediacy, thus creating space for the generation and consideration of alternatives. (Deacon 1997: 415)

In this experiment the opened space provided by the decreased saliency of the signs involved gives a survival advantage, but the point that Deacon repeatedly raises, and which is not supported by his limited use of Peirce, is that symbol use at the same time presents certain disadvantages. One of the dangers of symbol sign use is that in this situation signs gain the ability for self-replication independent of biological interpreters. It will be shown how the logic of this self-replication depends on an understanding of the legisign according to, at the very least, Peirce's 1903 classification of signs, but also on his late theory of the sign.

In a different source Deacon writes that the detachment from the subsymbolic "provides a reduction in the relative differences in associative salience by virtue of the partial dissociability of symbolic reference from more direct associations with other correlates and features of its object. Thus, prepotent and arousal influences are reduced" (Deacon 2006: 37). The learning child accrues a great deal of this grounding material, or salient primary iconic comparative material as well as indexical token object relations, the substance of which fleshes out symbolic relations, but as shown by the chimps and candy example it may be argued that the greater facility with symbols the subject has acquired, the lesser such comparative material is perceived. As Deacon puts it, the ascension of the representational hierarchy (in this case from icons to indexes to symbols) entails the decreased perception of the first two. Symbol use for Deacon makes it possible to dwell within ungrounded cognitive constructs or "virtual realities" (Deacon 1997: 452) that are independent of what he calls prepotent sensory stimuli, or what we are calling the subsymbolic.

Stressing the possibly maladaptive character of symbol use in Deacon's book would be misplaced were it not for the hyperbolic tone he takes in certain places on this topic, as if from his perspective these nefarious signs present a real danger such as here, where he writes,

We are not just a species that uses symbols. The symbolic universe has ensnared us in an inescapable web. Like a "mind virus," the symbolic adaptation has infected us, and now by virtue of the irresistible urge it has instilled in us to turn everything we encounter and everyone we meet into symbols, we have become the means by which it unceremoniously propagates itself throughout the world. (Deacon 1997: 436)

These symbol "savants" (Deacon 2012a: 37) or sign users that see symbols even where there are none are, as he writes, blinded to the subsymbolic by "a broader cognitive 
penumbra - extending beyond increased intelligence or language ability - cast by our neural evolution" (Deacon 2006: 27). And he makes the even stronger claim, that language is a "modern runaway process which may very well prove to be unsustainable into the distant future" and could be "just another short term, irreversible, selfundermining trend in hominid evolution" (Deacon 1997: 375). The idea of language as parasite seems closer to a delusion of the paranoid symbolic savant syndrome Deacon talks about than it is to a scientific inference. In any case, such generalizations do not follow from the simplified Peircean model he presents. It does however follow from a deep investigation of symbols as legisigns according to Peirce's mature sign theory as well as the later trichotomies of the interpretant and the dichotomy of the object, which investigation Deacon either had not done at the time, or at least does not make explicit within that book or any of his subsequent works.

This missing piece is partially addressed in the 2012 release The Symbolic Species Evolved, a collection of articles about The Symbolic Species by a variety of different scholars, written and published fifteen years later. The issue of the legisign is raised in this anthology by Deacon in an article called "Beyond the symbolic species". Here Deacon (2012a: 12) writes,

As Charles Peirce (1931) pointed out over a century ago, we must distinguish properties of the sign vehicle (which he terms a representamen), which can include being an arbitrarily defined (i.e. conventional) type of sign vehicle, from properties taken to link it to its object of reference [...] Peirce terms conventional sign vehicle types 'legisigns', and argues that symbols must also involve legisigns.

Within this classification all signs are combinations of the three sign dimensions (representamen, object, interpretant). This would yield twenty-seven distinct kinds of sign; however, certain logical restrictions are imposed, which limit the number of total signs in this typology. One such logical restriction is that all arguments are also symbols. There can be no iconic nor indexical arguments. Another such restriction is that all symbols are legisigns. In other words, there can be no dicent symbolic sinsigns, for example. After these and other restrictions are taken into consideration, we are left with a typology of ten distinct signs according to the 1903 classification (CP 2.2332.268). In effect, when Deacon uses Peirce in The Symbolic Species it should go without saying that when he classifies verbal language as symbolic it is implied that these symbols relate to their representamen as legisigns. In addition to the representamen relation (qualisign, sinsign, legisign), Deacon also chooses to ignore the interpretant relation (rhema, dicisign, argument), which pertains to the propositional load of the interpreted sign.

The ways in which a sign can relate to its object by means of icons, indexes, and symbols, has to do with the degree of constraint behind the connection to the object. 
Icons constrain the relation to the object to the first degree, through similarity; indexes to the second degree, through causality or proximity; and symbols to the third degree, through habit or convention. The ways in which a sign can relate to its interpretant are in the form of the rhema (term), dicisign (proposition), and argument. Rhema constrain the propositional load of the interpretant to the first degree, dicisigns to the second degree, and arguments to the third degree. The ways in which a sign can relate to its representamen have to do with the degree to which the vehicle of a given sign constrains its signification. Qualisigns exert the first degree of constraint, sinsigns the second, and legisigns the third. In the terms of the 1903 classification all these things should go without saying; however, to the naive reader of The Symbolic Species the use of the bare trichotomy of icon-index-symbol, while illuminating for the topic of verbal language acquisition, does not suffice to explain some of the features Deacon attributes to symbol use. At the very least a detailed inspection of the legisign would provide a missing link in his book between the detachment from the subsymbolic on the one hand, and the potential adaptive disadvantages he attributes to symbol use on the other hand. It happens that we must also consider the later divisions of the interpretant and the object from the post-1905 period of Peirce's work, but we leave that to the third Section.

Legisigns should be thought of as templates or replicators. One useful metaphor for describing legisigns is the mold used in casting. In casting one pours liquid metal into a mold of a given shape. When the metal cools it solidifies into the shape of the cast, say that of a metal rod. If the cast is the legisign, the rod is that legisign's sinsign or replica, and any number of such rods (replicas) can be made using the same cast (legisign). Such replicas themselves have no signification independent of their legisign. The legisign exerts its influence through any number of sinsigns The generalized potential of the legisign always consists in the fact that it provides the template for signification but remains unexpressed without the replica provided in the sinsign. The semiotic reasoning behind why legisigns signify through any number of different sinsign replicas has to do with their detachment from their context. The template created is applicable regardless of context so long as the rules of interpretation are available.

When the legisign realizes itself in the form of the sinsign its signification is predetermined. The possible plurality of its interpretants is highly limited. This referential restriction is what makes it possible for sinsign replicas to proliferate independently of biological subjects. Consider that icons for example are defined partially by the necessary plurality of their possible interpretations. Rhemas (the firstness of the interpretant relation) are the smallest propositional unit, dicisigns the second, and arguments the third. Terms or rhemas have the least restricted interpretive scope. Individual, unembedded terms can have many different meanings, but when put 
within the context of other words in a sentence their possible meaning becomes more limited. Dicisigns are more embedded within a referential context and therefore have a more concrete denotation and lower interpretative scope. Arguments, being the third and most generalized relation to the interpretant, have the most restricted interpretive scope. Deacon confidently asserts the fact that symbol use in verbal language and other media affords higher processing power, access to imaginary worlds, and mass replication. He also asserts the fact that these features of symbol use are a result of the ability of the symbol to detach itself from its subsymbolic, i.e. iconic and indexical grounds. As has been argued above, these two features are connected because the detachment from the subsymbolic entails a release from the context dependence of the object dimension, fixing signification across contexts. Winfried Nöth and Thomas L. Short in their respective meditations on the nature of legisigns provide the logical connection that Deacon does not make, as to why this loss of ground also makes it possible that certain symbols may lead to a situation in which some kinds of signs end up using organisms, rather than organisms using signs.

\section{Nöth and Short on the agency of symbols}

To suggest that a sign has a parasitic relation to its user implies that that sign is in some sense alive. This is Nöth's ostensible thesis in his "The life of symbols and other legisigns: More than a mere metaphor" (2014), where he contends that these signs have more similarities with living organisms than differences. But to say that they have more similarities than differences to organisms is not the same as to say that they are literally alive, or is it? He asks if symbols and other legisigns have life in a literal sense, "What are the really distinctive biological characteristics of symbols?" (Nöth in Romanini 2014: 175). "If the final cause of life is self-reproduction and self-replication, symbols are 'living realities' (CP 6.152), which have their teleology in self-replication, the creation of interpretants, and in determining future thoughts and interpretations" (Nöth in Romanini 2014: 175). Nöth supports this attribution of self-replication to symbols and legisigns with a series of direct references to Peirce's own writings (EP 2: 322, 1904; CP 2.222, 1903). Another biological characteristic of symbols and legisigns is their tendency to grow. This claim is also supported by Nöth with reference to many passages from Peirce (CP 3.302, CP 2.222, CP 2.302, CP 7.587). Contrary to the title of his work in fact it seems that this is just a rhetorical trick meant to further displace the conventional definition of agency, rather than to assert that symbols are literally alive. It is as if to say, if signs have agency - but only living organisms have agency -, then signs must be biologically alive, instead of simply saying that this equation of agency and biological life is too narrow. 
Perhaps Nöth is being intentionally controversial by taking the stance that symbols and other legisigns are biologically alive, because the rest of the observations he makes about the properties of these signs follow clearly from the writings of Peirce, such as those pointed out by T. L. Short, who insists on the teleological character and independent agency of symbolic legisigns, as distinct from other kinds of signs, which are otherwise relatively uncontested claims in Peirce scholarship.

It follows that the creation and replication of legisigns is goal-directed. In no other case is sign-production necessarily teleological, even though sign interpretation always is. (Short 1982: 293)

Short makes a big deal out of the teleological character of semiosis in Peirce's Theory of Signs (2007), much to the chagrin of some semioticians, who would prefer to align with the consensus that teleological top down explanations in science were left behind more than two hundred years ago. Defending the teleological character of some sign processes, Short writes,

Peirce's account of teleological explanation removes the mystery from teleology and shows it to be a rationally acceptable part of natural science. Peirce's teleology grounds his mature semiotic - in particular, its analysis of what it is to signify. Thus intentionality (chapter 1, section 3 ) acquires a naturalistic explanation. (Short 2007: 92)

Deacon's more recent book Incomplete Nature (2012) also addresses the teleological character of semiosis. He coins the term teleodynamics to explain how semiosis is at once irreducible to the morpho- and thermodynamics from which it arises and at the same time supervenes on (emerges from) them. Both Short and Deacon naturalize the explanation of the emergence of semiosis in the terms of a redefined teleology, a strategy which seems to be gaining traction in Peircean circles. Also confirmed by Short, this end-directed agency of symbolic legisigns (and their self-replication) depends fundamentally on their detachment from the subsymbolic.

The difference between symbolic and other legisigns is that the rules for indexical or iconic legisigns refer interpreters to indexical or iconic grounds, whereas the rules for symbolic legisigns are themselves grounds of significance (see 2.261). (Short 1982: 296)

Short maintains that, unlike qualisigns and sinsigns whose meanings can vary between different interpreters and in different contexts, the meaning of the replicas of legisigns are always fixed by the intention of the creator of that legisign. The purpose of legisigns persists across different domains and contexts. In this sense legisigns have an agency 
of their own that does not depend entirely upon the interpreter of the sign, although it may still depend on said interpreters for its existence. The degree of freedom of agency symbolic legisigns actually possess seems intentionally exaggerated by Nöth, but towards the end of the article even he pulls back enough to say that, whatever agency symbolic legisigns may have, biological users of said signs still also possess some agency and control over their duplication and interpretation.

The determination of the symbol user by the symbol does not exclude the partial determination of the symbol by those who use it. After all, the users' minds, their memories, and their experiences are the loci of the embodiment of the objects of the sign, so that the users are co-agents in the process of semiosis. (Nöth 2014: 8)

Nöth clearly backpedals at the end of the article from his hyperbolic thesis and admits that, though certain conditions do make it possible for a sign completely to become a replicator and subvert biological agency, such an instance would exemplify the death of that sign. For a sign to be a sign, it must be partially transformed by the interpreter. Holding to Peirce's original definition of the sign in so-called unlimited semiosis (CP 2.228), a sign is only a sign if the interpretant of that sign becomes the object of a new sign, and this only happens when that sign is interpreted and thus changed. This definition of the sign categorically excludes that situation where a sign detaches entirely and becomes nothing more than a totally formalized self-replicator, the best example of which is the computer program that independently processes semantic networks but is still incapable of creatively grounding said networks in new contexts. This definition of the sign (in unlimited semiosis) aligns with some other schools of semiotics, such as that of Juri Lotman, who also maintains that there must be an act of creative translation between incompatible code structures for there to be semiosis (Lotman 1977: 35). From this doctrine, only extreme cases of symbols are capable of totally losing their ground, losing their object dimension, where the process of translation becomes one of merely copying instead of translation. It is only symbols which can die.

\section{Peirce's late divisions for Deacon's The Symbolic Species}

So, contextualizing Deacon's use of symbol for language acquisition with Peirce's 1903 classification of triadic sign relations reinforces Deacon's claims about the possible disadvantages of symbol use because the 1903 classification specifies that all symbols are also legisigns, and it is from this sign aspect that the sign derives its capability for self-replication. However the elaboration of the Peircean model for the purposes of defending Deacon's work and addressing the relation between memes and signs does 
not stop at the 1903 classification. In fact between 1905 and 1908, the latest and most prolific period of Peirce's career, he produced additional divisions of the sign aspects, which shed even more light on these topics (CP 8.333). These divisions fracture the previous typology of ten signs into the notoriously complex and incomplete typology of sixty-six signs, and includes the trichotomies of the energetic, emotional, and logical interpretants, the immediate, dynamic, and final interpretants, and the dichotomy of the immediate and dynamic objects. In order to demonstrate how these divisions can lend a theoretical foundation to Deacon's hypotheses a few persistent ambiguities must be addressed.

Given that these divisions came so late, especially the trichotomy of the energetic, emotional, and logical interpretants, it is nowhere clearly sorted out how exactly these divisions relate to one another. Our primary interest here is the dichotomy of immediate and dynamic objects, because it is the interesting absence of a third term, the would-be final object, which tells us something about what happens when symbols become replicators. To understand what this absent final object would consist in were it to exist, we look to how the final interpretant relates to the two previous terms of lower addicity.

It is likewise requisite to distinguish the Immediate Interpretant, i.e. the Interpretant represented or signified in the Sign, from the Dynamic Interpretant, or effect actually produced on the mind by the Sign; and both of these from the (Final) ${ }^{1}$ Interpretant, or effect that would be produced on the mind by the Sign after sufficient development of thought. (CP 8.343)

One way this trichotomy is described is by plotting its terms onto the basic sign model (Fig. 1). In this case, the immediate interpretant corresponds to the representamen, the dynamic interpretant to the object, and the final interpretant to the interpretant, respectively. This shows how the immediate interpretant is that insofar as it is strictly represented by the sign, the dynamic interpretant is that in relation to its actual or so-to-speak real object in a given context, and the final interpretant is that ideal limit case which would express and encompass all possible perspectives on the sign within the group of inquirers. The dichotomy of immediate and dynamic objects can be understood in much the same way.

The immediate object, insofar as it is strictly represented by the sign and the dynamic object, is that in relation to its actual or real object in the world in a given context. It would follow from this that the hypothetical missing final object, corresponding to the interpretant dimension of the sign, would be that object in the

Here, instead of 'Final' interpretant, 'Normal' interpretant is written in the original text. T. L. Short persuasively establishes that the 'Normal' interpretant in this case is in fact just another name for the final interpretant. 
ideal limit case. Not merely standing for the real object in the world, this would be a context-independent object that would represent the object in all possible states of affairs independently of its actual state in a given moment or from the perspective of a given subject. Needless to say, a context-independent object relation is a contradiction of terms. Considered with respect to the addicity of the dimension, the fact that there are only two kinds of objects in this right is consistent with the fact that the object is the secondness of the sign, and the same extends to the representamen. The interpretant as the thirdness of the sign has three types, the object as the secondness two, and the representamen as the firstness only one. You can understand how it makes no sense to speak of any kind of representamen beyond the immediate representamen. The representamen is definitively immediate. A dynamic representamen would already imply an object and thus no longer be a representamen as such. But there is something more to all this.

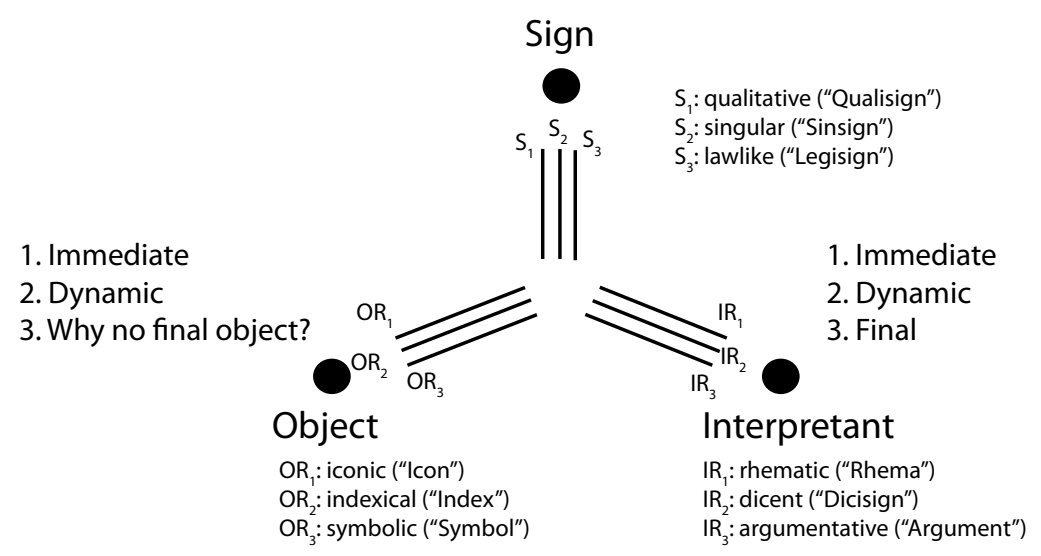

Figure 1. Michael H. G. Hoffman's "The 1903 classification of triadic sign relations" with additions. ${ }^{2}$

Our hypothesis is that the situation of the total habituation of the sign, the situation that Deacon describes as the cognitive penumbra and where "signs" subvert the agency of their users, is exactly this arrival of the final object. The reason there is no final object in the sign model is because the sign which completely detaches from the subsymbolic (the situation of the final object) is no longer a sign in the Peircean sense. No longer making inquiry into the state of the object within a given context, here the status of the

2 Hoffman, Michael H. G. "The 1903 classification of triadic sign relations” was accessed at http://www.digitalpeirce.fee.unicamp.br/hoffmann/p-sighof.htm. 
object is solidified much in the way in which Short describes the ultimate interpretant. Active inquiry is stopped by the solidification of a concrete habit of action. This frees the sign from its dependence on the context or ground, which can be understood in terms of its iconicity and indexicality. This logic also explains why replication takes over in this situation. What happens when a sign becomes untethered, when the so-to-speak final object arrives, when translation ends and copying begins, is that the object dimension itself collapses entirely and what we are left with is a dyadic pseudosign (Fig. 2).

Very well. If you are curious, this claim does have some precedent.

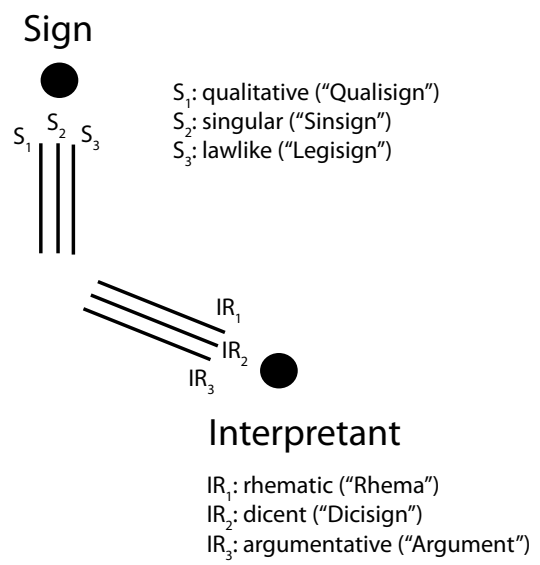

Figure 2. Michael H. G. Hoffman's “The 1903 classification of triadic sign relations” with a collapsed object dimension.

\section{What is the real difference between a meme and a sign?}

There was a fad that came to an end more or less about ten years ago, started by Richard Dawkins and carried on by others, known as the study of the meme. For obvious reasons, various semioticians took up the discussion, incredulous that Dawkins would so brazenly borrow from semiotic theory as if he were the first to come up with this idea and without making any reference to semiotic thinking properly. ${ }^{3}$ Attempts were made to reconcile semiotics and memetics, to try to articulate Dawkins' idea within extant semiotic models - however, to little avail. The project appears to have stalled

For a discussion of this, see Kilpinen 2008: 231. 
in its tracks despite, or perhaps because of, the centrality of memes in popular culture and technology. In fact, Deacon's going on about the possible maladaptation of symbol use and mind parasitism can be cast as little more than the first indications of what tater would become for him a pointed interest in memes, and in describing them in terms of sign theory. We have a hypothesis for why it is exactly that the comparison of sign and meme has more or less ceased. But first, let us get back to explaining the academic precedent for the connection between replication and the collapse of the triadicity of the sign into a dyad.

It might seem counterintuitive to say that an overgeneralized symbol could lose its object dimension considering that the symbol is part of the object trichotomy of icon, index, and symbol. The idea is that the total habituation of the sign relation so that it starts to self-replicate can only happen to symbols, but that when this happens they are no longer symbols properly, nor are they really signs. If we think of these collapsed signs as memes, we see that one semiotician writing about memes has come to the same conclusion:

Because memetics, with its notion of universal replication, recognizes only one of those dimensions that constitute signs, according to the general theory. It is aware of the interpretative dimension, but has little if anything to say about the representative dimension. Or, to make the point in Peirce's terms, memetics recognizes the relation between sign and its interpretant(s), but keeps silent about sign and object. (Kilpinen 2008: 7)

If we recall how the object dimension of the sign is that which expresses the sign's relation to the real or actual world, and that this necessarily implies the contextspecific situation of that sign, we can again see that in a later work titled "Memes as signs" Deacon (2004) also appears to corroborate the position that the replication of the habituated sign entails the collapse of the object dimension.

The problem of defining the difference between mere pattern and information is encountered in all realms of information processing and has the same unhelpful answer: what counts as information is context-dependent. The information some pattern can convey is both a function of its distinguishable physical characteristics with respect to other patterns and of its embeddedness in a living/semiotic system that can incorporate this into its functional organization. (Deacon 2004: 5; my emphasis, T.B.).

Put even more simply by Kalevi Kull already in 2000, “[...] a meme is a sign without its triadic nature [...]. Accordingly, the objects of copying are memes, whereas the objects of translation are signs" (Kull 2000: 116). 
But it happens that we have a fundamental disagreement with both Erkki Kilpinen and Terrence Deacon on the relation between memes and signs, and we find this disagreement a likely source for the decline of interest in the intersection of memetics and semiotics. By calling memes signs, Deacon opposes Dawkins'view that all cultural transmission occurs via replication, which is of course correct. In the process of translation, rather than transcription, new information is created, and this is semiosis, whereas in memetic replication no new information is added to the system; thus, if cultural transmission takes place solely via memes, then memes must also in some cases be signs because according to biosemiotics cultural evolution happens also beyond the strict confines of natural selection. In this sense Deacon approaches the debate about memes and signs from the wrong side altogether. It is not that all cultural transmission takes place via memes, while memes are also signs. Rather, cultural transmission takes place via memes as well as signs, but memes themselves are not signs.

In the first place, by a Peircean theory the most fundamental characteristic of the sign is its irreducible triadicity. It must have a representamen, an object, and an interpretant, but as established above, the habituation of the sign into a meme entails the collapse of this triadicity. In this respect the meme is not a type of sign. It is a pseudo-sign. In the second place, the Sebeokian tradition of Modelling Systems Theory, not to mention Juri Lotman's definition of the sign, both hold that semiosis entails the production of new information. The very term meme coming from Dawkins is defined precisely as that transmission which entails no new information, only replication. By this account it is strange indeed that both Kilpinen and Deacon, right about so many things, are so insistent that memes are signs.

So it can be said that the sign can pass through various stages, and that the memetic stage, the one at which a sign perishes, is the last stage. It is from this thought that we have developed a model for what we are calling the life cycle of the sign. It runs as follows. ${ }^{4}$

\section{Conclusion: Life cycle of the sign}

(a) Sign degeneration - this is when a sign is closer to an index or icon. The popular argument is that so-called degenerate signs are not signs because they lack thirdness. Our position on the other hand is that, while 'degenerate signs' indeed do not possess the extremity of thirdness characteristic of arguments, they retain the essential thirdness of their structure. They still have a representamen, an object, and an interpretant. These are subsymbolic signs, but remain signs nevertheless.

4 Partially, we owe the inspiration for this typology for the life cycle of the sign to Kalevi Kull. 
(b) Sign autonomization, or decontextualization - as opposed to symbols and other signs of extreme thirdness are much more autonomous as well as less bound to context than indexes and icons. Here, as a result of partial detachment from ground, plurality and polysemy decrease, but do not disappear. One example of this situation is the simple verbal propositional construct whose meaning, within a given group of inquirers, is well established and whose response is heavily habituated. The actual scope of variance in interpretation is highly restricted, but the sign retains its triadic structure. This is the limit case of semiosis but remains functionally significant. The chain of semiosis continues, unlimited semiosis persists, regardless of whether we can place where they fit into a Peircean 'argument' or 'symbol'.

(c) Sign collapse, or death - this is what we might call a meme, but would prefer to rename. As opposed to automatized or decontextualized signs, which are generally dominantly symbolic but still possess measures of polysemy and iconism, the best examples of collapsed or dead signs are formalized computer languages that can process semantic networks independently, yet lack the ability to reground said networks creatively in new contexts. Such systems depend, for their total formality, on internal noncontradiction and the absence of plurality, ambiguity, polysemy. When the symbolic legisign reaches such a point, it is no longer correct to refer to it as having an object dimension at all, as the production of the interpretant is solidified into a concrete habit of action. The object dimension of the sign collapses into the interpretant, the sign becomes dyadic, translation and unlimited semiosis end, and copying begins.

\section{References}

CP $=$ Peirce 1931-1958.

Deacon, Terrence 1997. The Symbolic Species: The Co-evolution of Language and the Brain. New York: W.W. Norton.

- 2004. Memes as signs in the dynamic logic of semiosis: Molecular science meets computation theory. In: Wolff, Karl Erich; Pfeiffer, Heather D.; Delugach, Harry S. (eds.), Conceptual Structures at Work. Dordrecht: Springer, 17-30.

- 2006. The aesthetic faculty. In: Turner, Mark (ed.), The Artful Mind: Cognitive Science and the Riddle of Human Creativity. Oxford: Oxford University Press, 21-56.

- 2012a. Beyond the symbolic species. In: Schilhab, Theresa; Stjernfelt, Frederik; Deacon, Terrence (eds.), The Symbolic Species Evolved. Dordrecht: Springer, 9-38.

- 2012b. Incomplete Nature: How Mind Emerged from Matter. New York: W.W. Norton.

$\mathrm{EP}=$ Peirce 1998 .

Kull, Kalevi 2000. Copy versus translate, meme versus sign: Development of biological textuality. European Journal for Semiotic Studies 12(1): 101-120.

Lotman, Juri 1977. The Structure of the Artistic Text. Ann Arbor: University of Michigan Press. 
Nöth, Winfried 2014. The life of symbols and other legisigns: More than mere metaphor? In: Romanini, Vinicius; Fernández, Eliseo (eds.) Peirce and Biosemiotics: A Guess at the Riddle of Life. Dordrecht: Springer, 171-182.

Peirce, Charles S. 1931-1958. Collected Papers of Charles Sanders Peirce. Cambridge: Harvard University Press. [Hartshorne, Charles; Weiss, Paul; Burks, Arthur W. (eds.). In-text references are to $\mathrm{CP}$, followed by volume and paragraph numbers.]

- 1998. The Essential Peirce. Vol. 2 (1893-1913). (Houser, Nathan; Kloesel, Christian, eds.) Bloomington: Indiana University Press. [In-text references are to EP.]

Short, Thomas L. 1982. Life among the legisigns. Transactions of the Charles S. Peirce Society 18(4): 285-310.

- 2007. Peirce's Theory of Signs. Cambridge: Cambridge University Press.

Stjernfelt, Frederik 2007. Diagrammatology: An Investigation on the Borderlines of Phenomenology, Ontology, and Semiotics. Dordrecht: Springer.

- 2012. The evolution of semiotic self-control. In: Schilhab, Theresa; Stjernfelt, Frederik; Deacon, Terrence (eds.), The Symbolic Species Evolved. Dordrecht: Springer, 39-64.

- 2014. Natural Propositions: The Actuality of Peirce's Dicisigns. Boston: Docent Press.

\section{Семиотический жизненный цикл и “Символический вид"}

В своей книге «Символический вид» (1997) Терренс Дикон уподобляет овладение вербальным языком первому и наиболее существенному эволюционному порогу, когда человек начинает использовать символы со всеми сопутствующими этому этапу адаптивными преимуществами. Но наряду с этими преимуществами он указывает в своей книге и на определенные недостатки как следствие употребления символов. При описании этих недостатков он бесцеремонно пользуется словами maladaptation, «паразитизм», “когнитивная полутень” и другими подобными гиперболическими терминами, не пытаясь при этом оправдывать эти эффекты знака в пределах пирсовской модели овладения языком, которая дала книге ее название. В более поздних работах Дикон пытается связать свои обобщения с теорией мема Ричарда Докинза. Дикона иногда упрекали за то, что он неточно или некорректно использует теорию знака Чарльза Пирса, защищая свои тезисы о мемах и символах. Проблема не в том, что теорию Пирса нельзя так использовать. На самом деле книга Дикона является успешным применением теории Пирса. Проблема состоит в том, что диконовская модель Пирса слишком проста. При более тщательном изучении модели знака зрелого Пирса можно усилить претензии Дикона к возможным недостаткам использования символа. Сохраняя теоретическую целостность книги «Символический вид», можно с помощью этой модели прояснить соотношение между мемами и знаками.

\section{Semiootiline elutsükkel ja "Sümboliline liik"}

Raamatus “Sümboliline liik” (1997) samastab Terrence Deacon verbaalse keele omandamise inimese poolt esmase ja olulisima evolutsioonilise lävepakuga, kust algab sümbolite kasutamine ühes kõigi sellega kaasas käivate adaptiivsete eelistega, ent nende eeliste kõrval viitab ta nii selles raamatus kui ka teisal teatavatele sümbolite kasutamisest tulenevatele ebasoodsatele 
asjaoludele. Nende ebasoodsate momentide kirjeldamiseks kasutab ta mitmeid hüperboolseid termineid: alakohasus, parasitism, tajuvari jm. Ta teeb seda möödaminnes, kas siis seoses mõnede laborikatsete tõlgendamisega või lihtsalt eraldiseisva üldistusena, kuid ei põhjenda märkide sellist toimimist kordagi peirce'iliku keeleomandamismudeli alusel, mis ometi on andnud tema raamatule pealkirja. Hilisemates teostes püüab Deacon suhestada neid üldistusi Richard Dawkinsi meemikäsitlusega. Deaconit on teinekord kritiseeritud selle eest, et ta kasutab Charles Peirce'i märgiteooriat ebatäpselt, kaitstes oma väiteid meemide ja sümbolite kohta. Probleem pole selles, et Peirce'i ei tohiks niimoodi kasutada. Tegelikult on Deaconi raamat tähelepanuväärne saavutus Peirce'i rakendamisel. Probleem on selles, et Deaconi peirce'ilik mudel on liiga lihtne. Tegelikult on Deaconi väidet sümbolite kasutamise kahjulike kaasnähtuste kohta võimalik tugevdada, rakendades täpsemini sajandivahetuse küpse Peirce’i märgimudelit. "Sümbolilise liigi" teoreetilist terviklikkust säilitades selgitab see meemide ja märkide vahelist suhet. 